\section{Issues in third-party intervention research and the role of destruction in conflict}

\section{Joel Potter and John L. Scott}

$\mathrm{I}$

terest in peacekeeping has blossomed since the end of the cold war. However, academics have only recently begun to study third-party interventions in conflict. ${ }^{1}$ We review the flourishing new literature on third-party intervention and point to areas of research in which economic theory may be useful to enhance scholars' and laymen's understanding. Our review highlights three aspects of the literature on thirdparty intervention. First, what are the goals of third parties who intervene and do they achieve those goals? Second, we review academic work concerning United Nations interventions. And third, paying attention to the recent extension of theory that models conflict as destructive, we suggest that this theory might be usefully grafted onto the theory of third-party intervention.

\section{Goals and success of interventions}

Regan discusses the issue of third-party objectives in civil conflict. He states that interventions can reduce or prolong conflict, depending on whether intervention is in behalf of the government or the opposition. He hypothesizes that early intervention in support of the government will shorten the conflict, while early intervention on behalf of the opposition will lengthen duration. He tests these hypotheses using a hazard model applied to monthly data on 150 conflicts drawn from 1944-1999. Contrary to his hypothesis, the empirical results suggest that early intervention in favor of the government does not statistically affect the duration of conflict. However, the estimates show that intervention on behalf of the opposition does tend to lengthen the duration of conflict, although the substantive impact is small. When Regan takes account of the type of intervention - military or economic - he finds that third-party involvement greatly increases the expected duration of conflict. Even neutral interventions - those made on both sides of a conflict — are found to lengthen conflict duration. He writes:

"Clearly, the notion of what constitutes an effective intervention strategy is an important element in understanding how civil conflicts are managed. When focusing exclusively on military and economic forms of outside interventions, conflicts appear to be not only ineffectively managed, but the interventions themselves also appear to prolong the conflict ... The results further suggest that policy makers need to think more critically about the role of military or economic interventions if their objective is to manage the violent aspects of a conflict."
Collier and Sambanis cite Regan as the gold standard in third-party intervention research. But they view Regan's work as lacking crucial normative content, because third parties likely have strong views on "the perceived justice of the rebellion." This critique might extend to Siquira, who assumes that third parties only value peace. ${ }^{3}$ Collier and Sambanis also note that even if the third party seeks swift conflict resolution, it may not be clear which combatant is strongest; that researchers lack data on the cost of both conflict and intervention; and that Regan omits important variables (although Collier and Sambanis do not specify which variables).

If, as Regan finds, third parties do actually prolong conflict, then either they wish to prolong conflict or their actions work against their intentions. However, other factors which are not currently accounted for, such as the intensity of an ethnic conflict, may lead to both third-party involvement and longer expected conflict duration (econometrically speaking, this is an endogeneity problem). Elbadawi and Sambanis, for example, effectively deal with endogeneity issues. They employ economic theory to ascertain how intervention affects conflict, basing their empirical work on the theoretical economic approach of Intriligator and Brito. Elbadawi and Sambanis predict that external assistance to a rebel party will increase duration of conflict, ceteris paribus, later theoretically confirmed by Chang, Potter, and Sanders, and by Chang and Sanders. This is because external intervention will serve to raise rebel capabilities, allowing them to continue their resistance. ${ }^{4}$

But Elbadawi and Sambanis note that this causal relation between intervention and duration is difficult to show empirically. Does intervention on behalf of rebels cause a longer lasting conflict, or do longer lasting conflicts lead to external intervention? To resolve this issue Elbadawi and Sambanis employ the econometric technique of instrumental variables. First, they estimate a random effects probit model to predict interventions. They find that several factors lead to external intervention. Civil wars with high casualties invite intervention; ethnic conflicts invite less intervention; and intervention is more likely when war was present in the previous period. Next, they use these results in an ordered probit model to estimate the duration of conflict. As predicted by theory, the coefficient of expected intervention is positive; hence, they conclude that external intervention on behalf of rebels will increase the duration of conflict.

Chang, Potter, and Sanders, and Chang and Sanders do not assume that interveners 
value either peace or war. Instead, they assume that third parties attempt to maximize their own utility with regard to their geopolitical, ideological, or religious interests. In these game-theoretic models the third party subsidizes an ally, which may either prevent or trigger a conflict. Likewise, Chang, Potter, and Sanders develop a theoretical model that demonstrates that third parties are sometimes not interested in peace. In their model a third party may assist an ally by choosing a military subsidy that will reduce the ally's cost of arming. This subsidy may prevent war if the conflict occurs on the ally's land, or cause war if the conflict occurs on the opponent's land. Hence, third parties may be either peacemakers or peacebreakers. ${ }^{5}$

Given the complex nature of third-party intervention, a model that can account for multiple goals for the intervener might prove valuable. An intervening party might simultaneously value an ally possessing a territory and value peace; hence, research on this type of systematic decisionmaking would be preferable to a single-choice variable model.

\section{United Nations interventions}

The United Nations is the market leader of the peacekeeping industry. Even when it is not directly involved, it is likely that the U.N. has given explicit approval for the country/coalition that is directly involved; ${ }^{6}$ hence most academic research on intervention examines U.N. peacekeeping missions.

The notion of peacekeeping/peacebuilding is evolving. After the cold war, the United Nations became involved in conflicts throughout the world. In the early 1990s, peacebuilding referred to missions carried out through diplomacy and mediation efforts with the United Nations. By the end of the 1990s, peacebuilding became the choice word for multidimensional and increasingly intrusive missions with the goal of stabilizing societies/states. Recently the U.N. has expanded its interventions. From 1999 through 2006, U.N. peacekeeping missions increased by more than 500 percent. This surpassed the deployments of all other regional peacekeeping organizations combined. Benner, Binder, and Rottman state: "In mid-2006, the U.N. Peacebuilding Commission became operational, giving formal recognition to the central importance of peacebuilding for the world body." The authors define peacebuilding as missions undertaken by both civilian and military personnel mandated to consolidate peace and to prevent a recurrence of fighting in a country emerging from war. ${ }^{7}$

Recent research investigates whether U.N. peacekeeping missions produce peace and stability. Collier, et al. emphasize economic recovery as a postconflict priority. However, they also argue that reducing the probability of future conflict is another important priority. The researchers conclude that while economic aid and policy can support the first priority, the United Nations is crucial in supporting the latter. They find that a 100 percent increase in U.N. spending leads to a 9 percentage points decrease in the probability of future conflict (from 40 percent to 31 percent). They also propose that democratic elections in a country that has experienced conflict will reduce the probability of further violence; but their data do not support this hypothesis. Countries that have an election after experiencing civil war are just as likely to relapse into conflict as countries that do not have a postwar election. ${ }^{8}$

Studies such as those by Fortna and by Doyle and Sambanis have found that the U.N. does foster peace while other studies such as Gilligan and Sergenti cast doubt on the issue. Thus, Fortna finds evidence that U.N. peacekeeping missions are not random. Instead, peacekeepers are generally sent to severe conflicts. In addition, after controlling for conflict specific factors (i.e., duration), she finds that peacekeeping missions are in fact successful for keeping the peace. Gilligan and Sergenti are suspicious of Fortna's results because the cases in which the U.N. intervened were different from those in which it did not; thus, Gilligan and Sergenti conclude that Fortna's estimates of the effects of the U.N. operations were largely extrapolations from the available data. ${ }^{9}$

Doyle and Sambanis find that U.N. peacekeeping missions are positively correlated with peace in a region. They make the case that the United Nations brings about peace where it would not have otherwise existed. The researchers found that it was easier to build peace (1) in nonidentity wars; (2) in countries with relatively high development levels; and (3) following long wars of low intensity. But Gilligan and Sergenti argue that Doyle and Sambanis do not deal with serious issues in their sample. They point out that the United Nations only carried forth an actual postconflict role when disputes had more than 148 cumulative battle deaths. Gilligan and Sergenti conclude that Doyle and Sambanis's predictions concerning a dispute with a small number of deaths are not based on the data: ${ }^{10}$

“Speaking metaphorically, Doyle and Sambanis's analysis compares apples and oranges or more precisely it makes inferences about the effect of a given treatment on apples based on observations of the effect of the treatment on oranges."

To account for this apples and oranges issue, Gilligan and Sergenti pre-process their data using matching techniques suggested by Ho, Imai, King, and Stuart. These are designed to more reliably infer causality. They find that postconflict involvement increases the chance for peace but that U.N. involvement does not foster peace when war is ongoing, casting doubt on the effectiveness of the organization's peacemaking mission. They also note that their own methods may omit unobservable factors which may cause both war and U.N. involvement. To resolve this issue, researchers might use instrumental variables, as in Elbadawi and Sambanis, which we previously detailed. ${ }^{11}$

What is the true goal (or goals) of the United Nations? The single goal of securing peace might be too simplistic an answer. As Balch-Lindsay and Enterline assert, "[p]olicymakers often trumpet the potential for third parties to stop the killing associated with civil wars, yet third parties as strategic actors also have incentives to encourage longer civil wars." 12 


\section{Destruction in conflict}

In 2000, the Journal of Conflict Resolution dedicated an entire issue to the economics of conflict featuring leading scholars in the field. Articles by Gershenson and Grossman and by Garfinkel and Skaperdas explored conflict with perfect information. Both utilized a two-party framework where both sides compete for a resource. In Gershenson and Grossman the parties compete over territory (i.e., land). They do not model the destructiveness of conflict, implicitly assuming that the amount of destruction in any conflict is zero-that territories will be unscathed in an armed conflict. In Garfinkel and Skaperdas's article the parties produce a civilian good that gives utility and a military good that may only be used to potentially capture or defend supplies of the civilian good. In contrast with Gershenson and Grossman, Garfinkel and Skaperdas allow for destruction in conflict. They conclude that as conflict becomes more destructive, other things equal, war becomes less likely. ${ }^{13}$

In an extension of Gershenson and Grossman, Chang, Potter, and Sanders use the same approach, but relax a key assumption - they introduce a nonnegative destruction term. ${ }^{14}$ They model conflict in one time period as reducing the land's or territory's value in the following period. Hence, an aggressor who wishes to take control of a territory, in part because of its economic value, faces a dilemma. On the one hand, the aggressor must engage in armed conflict in order to secure the desired territory. On the other hand, engaging in armed conflict reduces the value of the territory the aggressor wishes to possess. This model also assumes that the amount of destruction may vary from conflict to conflict. Advances in technology allow aggressors more freedom of choice in the amount of destruction they cause. For instance, precision guided and remotely targeted munitions may allow an aggressor to reduce the amount of destruction necessary to secure a territory. Alternatively, with greater mobility and advanced destructive munitions, the aggressor may threaten greater destruction. Accordingly, the model predicts that as conflicts become more destructive, ceteris paribus, they will end more quickly. Additionally, the authors assume that parties cannot choose the level of destruction they desire to wreak on the disputed territory; rather, they can only choose the level of resources devoted to the conflict. More resources increase the likelihood of victory, ceteris paribus. So when an aggressor increases the quantity of resources devoted to the war, other things equal, their chance of securing the territory increases. But, according to the model, the level of resources is independent of the amount of destruction. Given these assumption, the aggressors have no choice concerning the level of destruction wrought. This is also true for Gershenson and Grossman and for Garfinkle and Skaperdas. Future research on thirdparty intervention may model opponents as being able to choose both an optimal amount of resources and destruction.
Conclusion

Research into third-party intervention has grown quickly since its recent birth Scholars have begun to grapple with complex theoretical relations that are complicated by the possibility that we are uncertain about the goals of the parties involved - whether they seek peace, whether they favor one party, or whether they have more complex motivations. Empirical work has attempted to untangle the effects of intervention in either prolonging conflict or promoting peace. The flexible statistical model of Elbadawi and Sambanis stands out at this time. Finally, researchers have begun to model the destruction of conflict, pointing toward a new direction in modeling the incentives and effects of not only conflict in general, but also specifically of third-party intervention.

Notes

Joel Potter is an Assistant Professor of Economics in the Mike Cottrell School of Business, North Georgia College and State University, Dahlonega, GA, U.S.A. He may be reached at jmpotter@ngcsu.edu. John L. Scott is an Associate Professor of Economics in the Mike Cottrell School of Business, North Georgia College and State University, Dahlonega, GA, U.S.A. He may be reached at jlscott@ngcsu.edu.

1. Interest: Fortna and Howard (2008); recently: Regan (2002).

2. Regan (2002); quote from p. 72.

3. Collier and Sambanis (2002, pp. 7-8); Siquira (2003). Researchers that assume the only goal of the third party is peace are called idealists by Regan (1998).

4. Elbadawi and Sambanis (2000); Intriligator and Brito (1988); Chang, Potter, and Sanders (2007b); Chang and Sanders (2008).

5. Both references are to Chang, Potter, and Sanders (2007b).

6. Fortna and Howard (2008).

7. U.N. became involved: Johnstone, Tortolani, and Gowan (2006); early 1990s: Benner, Binder, and Rottman (2007); expanded missions: Johnstone, Tortolani, and Gowan (2006); quote: Benner, Binder, and Rottman (2007, p. 9).

8. Collier, Hoeffler, and Soderbom (2008).

9. Fortna (2004); Doyle and Sambanis (2000); Gilligan and Sergenti (2008). 
(C) www.epsjournal.org.uk - Vol. 5, No. 1 (2010)

10. Doyle and Sambanis (2000); Gilligan and Sergenti (2008); quote to follow: Gilligan and Sergenti (2006, pp. 6-7).

11. Gilligan and Sergenti (2008); Ho, Imai, King, and Stuart (2007); Elbadawi and Sambanis (2000).

12. Balch-Lindsay and Enterline (2000, p. 615).

13. Gershenson and Grossman (2000); Garfinkel and Skaperdas (2000).

14. Chang, Potter, and Sanders (2007a).

\section{References}

Balch-Lindsay, D. and A.J. Enterline. 2000. "Killing Time: The World Politics of Civil War Duration, 1820-1992.” International Studies Quarterly. Vol. 44, No. 4, pp. 615-642.

Benner, T., A. Binder, and P. Rotmann. 2007. "Learning to Build Peace? United Nations Peacebuilding and Organizational Learning: Developing a Research Framework." Global Public Policy Institute Research Paper Series. GPPi Research Paper No. 7, pp. 1-81.

Chang, Y.-M., J. Potter, and S. Sanders. 2007a. "The Fate of Disputed Territories: An Economic Analysis.” Defence and Peace Economics. Vol. 18, No. 2, pp. 183-200.

Chang, Y.-M., J. Potter, and S. Sanders. 2007b. "War and Peace: Third-party Intervention in Conflict." European Journal of Political Economy. Vol. 23, No. 4, pp. 954-974.

Chang, Y.-M., and S. Sanders. 2009. "Raising the Cost of Rebellion: The Role of Third-party Intervention in Intra-state Conflict." Defence and Peace Economics. Vol. 20, No. 3, pp. 149-169.

Collier, P. and N. Sambanis. 2002. "Understanding Civil War: A New Agenda." Journal of Conflict Resolution. Vol. 46, No. 1, pp. 3-12.

Collier, C., A. Hoeffler, and M. Soderbom. 2008. "Post-Conflict Risks." Journal of Peace Research. Vol. 45, No. 4, pp. 461-478.

Doyle, M.W. and N. Sambanis. 2000. "International Peacebuilding: A Theoretical and Quantitative Analysis.” American Political Science Review. Vol. 94, No. 4, pp. 779-801.

Elbadawi, I.A. and N. Sambanis. 2000. "External Interventions and the Duration of Civil Wars.” Mimeo. Washington, D.C.: World Bank.

Fortna, V.P. 2004. "Does Peacekeeping Keep Peace? International Intervention and the Duration of Peace after Civil War.” International Studies Quarterly. Vol. 48, No. 2, pp. 269-292.

Fortna, V.P. and L.M. Howard. 2008. "Pitfalls and Prospects in the Peacekeeping
Literature." Annual Review of Political Science. Vol. 11, pp. 283-301.

Garfinkle, M.R. and S. Skaperdas. 2000. "Conflict Without Misperceptions or Incomplete Information: How the Future Matters.” Journal of Conflict Resolution . Vol. 44, No. 6, pp. 793-807.

Gershenson, D. and H.I. Grossman. 2000. “Civil Conflict: Ended or Never Ending?” Journal of Conflict Resolution. Vol. 44, No. 6, pp. 807-821.

Gilligan, M.J. and E.J. Sergenti. 2008. "Do U.N. Interventions Cause Peace? Using Matching to Improve Causal Inference." Quarterly Journal of Political Science. Vol. 3, No. 2, pp. 89-122.

Gilligan, M.J. and E.J. Sergenti. 2006. "Do U.N. Interventions Cause Peace? Using Matching to Improve Causal Inference." Unpublished manuscript.

Ho, D., K. Imai, G. King, and E. Stuart. 2007. "Matching as Non-parametric Preprocessing for Reducing Model Dependence in Parametric Causal Inference." Political Analysis. Vol. 15, No. 3, pp. 199-236.

Intriligator, M. and D. Brito. 1988. "A Predator-Prey Model of Guerrilla Warfare." Synthesis. Vol. 76, No. 2, pp. 235-249.

Johnstone, I., B.C. Tortolani, and R. Gowan. 2006. "The Evolution of U.N. Peacekeeping: Unfinished Business.” Die Friedenswarte (Journal of International Peace and Organization). Vol. 80, No. 3-4, pp. 55-71.

Regan, P. 1998. "Choosing to Intervene: Outside Intervention in Internal Conflicts." The Journal of Politics. Vol. 60, No. 3, pp. 754-779.

Regan, P. 2002. "Third-party Interventions and the Duration of Intrastate Conflicts." Journal of Conflict Resolution. Vol. 46, No. 1, pp. 55-73.

Siqueira, K. 2003. "Conflict and Third-party Intervention." Defence and Peace Economics. Vol. 14, No. 6, pp. 389-400. 